Przegląd Badań Edukacyjnych

ISSN 1895-4308

nr $18(1 / 2014)$, s. 171-194

METODY ZBIERANIA

I ANALIZY DANYCH

W BADANIACH

EDUKACYJNYCH

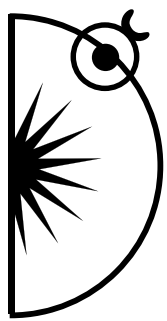

Hanna Rudomska

\title{
Analiza jakościowa zachowań prawidłowych i nieprawidłowych uczniów głuchoniewidomych na tle edukacji rodzinnej i instytucjonalnej - rozwiązania metodologiczne
}

DOI: http://dx.doi.org/10.12775/PBE.2014.012

\section{Metodologiczne założenia badań własnych}

Wiedza naukowa w sposób znaczący powinna odróżniać się od wiedzy potocznej. Powinna ją przewyższać między innymi poprzez stosowanie określonej metodologii badawczej. Stąd celem nauki powinno być dostarczanie dającej się zweryfikować wiedzy, która pozwala nam opisać oraz wyjaśnić, przewidzieć i zrozumieć interesujące nas zjawisko empiryczne (Szlachta, 2004, s. 687).

Stąd, badając rzeczywistość powinniśmy zastosować określone reguły badań oraz postępować zgodnie z etapami procesu badawczego.

Każde badanie naukowe wymaga typowych czynności badawczych, żeby można było prawidłowo weryfikować założenia badawcze oraz osiągnąć wysoki stopień wiarygodności wyników badań. W związku z powyższym konieczne jest przyjęcie, zgodnie z literaturą metodologiczna, określonej procedury postępowania badawczego. Oznacza to, iż badacz nie może pominąc żadnego z etapów procesu badawczego, by nie zakłócić logicznej zasady ciagłości i wynikania. Zatem, prowadzenie badań musi odpowiadać powszechnie uznanym kryteriom poznania naukowego i metodologicznym regułom, takim jak: 
- obiektywizm badań;

- adekwatność zastosowanych środków;

- reprezentatywność uzyskanych tą drogą wyników;

- dobór reprezentatywnej próby badawczej;

- przestrzeganie etapów badawczych zaplanowanego postępowania (Pilch, Lepaczyk 1995, s. 46).

Zgodnie z tym założeniem poniżej określony zostanie przedmiot i cel badań; problemy badawcze; metody; techniki i narzędzia badawcze wykorzystane w celu zebrania danych empirycznych.

\section{Przedmiot i cele badań}

Zakres zjawisk objętych badaniem powinien pokrywać się z zakresem rzeczywistości interesującej badacza jako przedmiot jego dociekań (Nowak, 1985, s. 44). W metodologii nauk społecznych badacze różnie definiują zarówno przedmiot, jak i cel badań naukowych. Uwzględniając definicje metodologiczne oraz społecznie ważne przesłanki przedmiotem prezentowanych badań uczyniono zagadnienie:

funkcjonowania społecznego dzieci głuchoniewidomych opisywane w oparciu o zachowania prawidlowe i nieprawidlowe przejawiane pod wptywem środowiska rodzinnego i środowiska szkolnego.

Tak przedstawiony przedmiot badań wytycza cele, jakie postawiono przed podjęciem badań. Nie każde poznanie może być uznane za poznanie naukowe. Aby można je było za takie uznać, musi ono realizować określone cele (Brzeziński 2004, s. 30).

Mając na uwadze podejścia metodologów celem poznawczym badań własnych_było:

- poznanie i opis przejawów zachowań prawidlowych i zachowań nieprawidlowych u dzieci głuchoniewidomych,

- poznanie i opis oddzialywań środowiska rodzinnego i środowiska szkolnego na przejawy zachowań prawidłowych i nieprawidłowych u dzieci gluchoniewidomych;

Biorąc pod uwagę, że zarówno przedmiot, jak i cele badań stanowią podstawę dalszych przedsięwzięć badawczych, a zarazem umożliwiają dalsze postępowanie badawcze następnie określenia wymagają problemy badawcze. 


\section{Problemy badawcze}

Określone powyżej przedmiot i cel badań determinują sposób sformułowania problemu badawczego lub zespołu problemów badawczych.

Uwzględniając kryteria metodologiczne poprawności formułowania problemów, a także biorąc pod uwagę wcześniej przedstawiony przedmiot i cele badań sformułowano następujące problemy główne:

1. Jak funkcjonują społecznie, w kontekście zachowań prawidłowych i nieprawidłowych, dzieci głuchoniewidome w wyniku edukacji rodzinnej?

2. Jak funkcjonują społecznie, w kontekście zachowań prawidłowych i nieprawidłowych, dzieci głuchoniewidome w wyniku edukacji instytucjonalnej?

Ze zrozumiałych względów problemy główne wymagają uszczegółowienia problemami cząstkowymi, które dla celów badawczych są bardziej przydatne.

Zatem problemy szczególowe do pierwszego problemu głównego przedstawiają się następująco:

1.1. Jakie postawy rodzicielskie przejawiaja rodzice wobec dziecka gluchoniewidomego?

1.2. Czy postawy rodzicielskie wobec dziecka gtuchoniewidomego zmieniaja się wraz z jego dorastaniem?

1.3. Jakie style i metody wychowawcze stosuja rodzice wobec dziecka gluchoniewidomego?

1.4. Czy style i metody wychowawcze stosowane przez rodziców wobec dziecka głuchoniewidomego zmieniaja się wraz z jego dorastaniem?

1.5. Jakie, wedtug rodziców, zachowania prawidłowe i nieprawidtowe przejawia dziecko głuchoniewidome do czasu podjęcia nauki w Oddziale dla Dzieci i Młodzieży Gtuchoniewidomej w Ośrodku Szkolno - Wychowawczym Nr 1 dla Dzieci i Młodzieży Stabo Widzacej i Niewidomej im. L. Braille'a w Bydgoszczy?

1.6. Jakie, wedlug rodziców, zachowania prawidłowe i nieprawidtowe przejawia dziecko głuchoniewidome po podjęciu nauki w Oddziale dla Dzieci i Młodzieży Gtuchoniewidomej w Ośrodku Szkolno-Wychowawczym Nr 1 dla Dzieci i Młodzieży Słabo Widzqcej i Niewidomej im. L. Braille'a w Bydgoszczy? 
1.7. Czy, wedlug rodziców, zmienia się zachowanie dziecka gluchoniewidomego (pod katem zachowań prawidlowych i nieprawidlowych) po podjęciu nauki w Oddziale dla Dzieci i Młodzieży Gtuchoniewidomej w Ośrodku Szkolno-Wychowawczym Nr 1 dla Dzieci i Młodzieży Stabo Widzacej i Niewidomej im. L. Braille'a w Bydgoszczy?

1.8. Czy rodzice, jeśli widzq zmiany w zachowaniu się dziecka gluchoniewidomego (pod katem zachowań prawidłowych i nieprawidlowych) po podjęciu nauki w Ośrodku, potrafia podać przyczynely dlaczego się tak dzieje?

1.9. Czy rodzice dostrzegaja różnice między zachowaniem dziecka gluchoniewidomego (w kontekśsie zachowań prawidlowych i nieprawidłowych) w doти i w Oddziale dla Dzieci i Młodzieży Gluchoniewidomej w Ośrodku Szkolno-Wychowawczym Nr 1 dla Dzieci i Młodzieży Stabo Widzqcej i Niewidomej im. L. Braille'a w Bydgoszczy? 1.10. Czy rodzice, jeśli widzq różnice w funkcjonowaniu dziecka gluchoniewidomego (w plaszczyźnie zachowań prawidtowych i nieprawidlowych) w doти i w Ośrodku potrafia podać przyczynęly, dlaczego się tak dzieje?

Natomiast drugi problem główny uszczegółowiono poniższymi problemami cząstkowymi:

2.1. Jakie, wedlug wychowawców, zachowania prawidtowe i nieprawidlowe przejawiaja dzieci gluchoniewidome po przyjęciu do Oddziału dla Dzieci i Młodzieży Gluchoniewidomej w Ośrodku Szkolno-Wychowawczym Nr 1 dla Dzieci i Młodzieży Stabo Widzacej $i$ Niewidomej im. L. Braille'a w Bydgoszczy?

2.2. Jakie dziatania podejmuja wychowawcy wobec gluchoniewidomych dzieci, w celu niwelowania zachowań nieprawidtowych $i$ wzmacniania zachowań prawidlowych?

2.3. Czy i jak, wedtug wychowawców, zmienia się zachowanie dzieci gluchoniewidomych w płaszczyźnie zachowań prawidtowych i nieprawidlowych $w$ wyniku edukacji instytucjonalnej-podejmowanych wobec niego systemowych oddzialywań edukacyjnych, wychowawczych i rewalidacyjnych?

2.4. Czy wychowawcy, jeśli widza zmiany w zachowaniu się dzieci gluchoniewidomych (w obszarze zachowań prawidłowych i nieprawidłowych) po podjęciu nauki w Oddziale dla Dzieci i Młodzieży Gtu- 
Hanna Rudomska Analiza jakościowa zachowań prawidłowych i nieprawidłowych...

choniewidomej w Ośrodku Szkolno-Wychowawczym Nr 1 dla Dzieci i Młodzieży Stabo Widzacej i Niewidomej im. L. Braille'a w Bydgoszczy, potrafia podać przyczynęly, dlaczego się tak dzieje?

2.5. Czy wychowawcy dostrzegaja różnice między zachowaniem dzieci gluchoniewidomych ( $w$ relacji zachowania prawidtowe - zachowania nieprawidtowe) po dluzszych pobytach $w$ domu $i$ w Oddziale dla Dzieci i Młodzieży Gluchoniewidomej w Ośrodku Szkolno-Wychowawczym Nr 1 dla Dzieci i Młodzieży Stabo Widzacej i Niewidomej im. L. Braille'a w Bydgoszczy?

2.6. Czy wychowawcy, jeśli widza różnice w funkcjonowaniu dzieci gluchoniewidomych ( $w$ kontekście zachowań prawidłowych i nieprawidlowych) po dhuższych pobytach w domu i w Ośrodku potrafia podać przyczynęly, dlaczego się tak dzieje?

Przedstawione problemy badawcze mają postać pytań dopełnienia - pytań, które nie dają jednoznacznej odpowiedzi: „tak” lub „nie”, tak jak pytania rozstrzygnięcia. Są to pytania wymagające poszukiwań i inwencji twórczej. Zgodnie ze stanowiskiem Tadeusza Pilcha spełniają również 3 zadania dotyczące:

- wyczerpania zakresu tematu,

- ukazania kierunku poszukiwań badawczych,

- wyjaśnienia tematu (Pilch, Baumann, 2001, s. 192).

\section{Model metodologiczny badań}

Problemy badawcze determinują przyjęty przez badacza model metodologiczny badań. Stąd, w celu uzyskania odpowiedzi, na postawione w taki sposób pytania, należy przyjąć odpowiedni model organizujący czynności badawcze i porządkujący dane empiryczne.

W badaniach społecznych przyjmuje się dwie strategie.

„Pierwsza strategia, akceptująca stanowisko indukcjonizmu, zaleca najpierw badania empiryczne, a następnie formułowanie uogólnień i teorii opartych na zebranych danych. W strategii tej za podstawową metodę uznaje się indukcję pozwalającą formułować nowe uogólnienia (twierdzenia) i sprawdzać ich prawomocność przez ufne odwoływanie się do wrażeń zmysłowych. Druga strategia sugeruje odwrotne postępowanie, rozpoczynanie od konstruowania śmiałej hipotezy, dzięki której zyskuje się punkt orientacyjny, umożliwiający poruszanie się w świecie badań empirycznych. Strategia ta - związana ze stanowiskiem hipotetyzmu, krytycznym wobec indukcjonizmu i upatrującym 
właściwej metody nauk empirycznych w tzw. metodzie hipotetyczno - dedukcyjnej, polega na odważnym stawianiu hipotez, a następnie ich krytykowaniu za pomocą procedury dedukcyjnej, umożliwiającej konfrontację hipotezy z doświadczeniem" (Szlachta, 2004, s. 688).

Mając na uwadze, że wnioski ogólne - uogólnienia, będą wyprowadzane z przesłanek obejmujących poszczególne przypadki przyjęto model metodologiczny indukcjonizmu.

„Metoda analizy indukcyjnej związana ze stanowiskiem indukcjonizmu głoszącym, że jedynym źródłem wiedzy jest doświadczenie, odpowiada przede wszystkim dyscyplinom empirycznym i opisowym, posługującym się w opisie językiem obserwacyjnym, zdolnym do formułowania wąskich uogólnień empirycznych, czyniąc w ten sposób zadość wymogom opisowej wersji nauki, formułowanym w postaci tezy głoszącej przekładalność twierdzeń teoretycznych na twierdzenia o przedmiotach obserwowalnych, uznaje bowiem za ostateczny, epistemologicznie niekwestionowalny fundament wiedzy naukowej fakty empiryczne dane w doświadczeniu. Nauki społeczne wykorzystują tę metodę głównie w badaniach jakościowych"(Szlachta, 2004, s. 692).

\section{Rodzaj podjętych badań}

Przyjęty model metodologiczny badań wskazuje, że zasadne wydaje się podjęcie badań jakościowych. Jednakże w badaniach społecznych stosowane są dwa rodzaje badań - badania ilościowe i badania jakościowe. Poniżej przedstawione zostaną ich cechy charakterystyczne, na podstawie których będzie wynikać, że przyjęte w prezentowanej pracy badania jakościowe mają swoje uzasadnienie.

„Traktując rzecz modelowo, można wyróżnić dwie drogi postępowania badawczego. Podążając jedną z nich badacz podporządkowuje się metodologii, opartej na założeniach filozofii pozytywistycznej, posługuje się metodami ilościowymi. Zakłada on wówczas istnienie obiektywnego świata, możliwość równie obiektywnego poznania go za pomoca precyzyjnie skonstruowanych narzędzi. Bada więc tylko poddające się pomiarowi obiekty, poszukuje między nimi zależności przyczynowo-skutkowej, aby odkrywszy je, móc wywierać skuteczniejszy wpływ na rzeczywistość społeczną.

Druga droga jest mniej wyrazista i precyzyjna. Badacz ma świadomość jedności ze światem (brak dualnego podziału na poznającego i świat poznawany), zakłada subiektywny charakter własnej wiedzy i poznania. Uważa, że badając rzeczywistość społeczną musi posługiwać się narzędziami „miękkimi”, elastycznymi, które łatwo może zmienić lub przekształcić po to, aby dostrzec 
w zjawisku nieprzewidziane wcześniej aspekty. Posługuje się metodami jakościowymi, za pomocą których może docierać bardziej „,W głąb” badanego zjawiska, a także poszerzyć perspektywę jego oglądalności (kontekst)" (Pilch, Baumann, 2001, s. 268).

Wobec powyższych stwierdzeń, oraz mając na uwadze podjętą problematykę badawczą i wskazania związane z modelem metodologicznym badań w niniejszej pracy zastosowano badania jakościowe.

\section{Dokonany wybór strategii jakościowych podyktowany był następują- cymi argumentami:}

- problem zachowań prawidłowych i nieprawidłowych przejawianych przez dzieci głuchoniewidome stanowi temat wielu dyskusji zarówno rodziców, jak i specjalistów zajmujących się edukacją głuchoniewidomych. Tylko jakościowa analiza i ocena problematyki pozwoli na poszerzenie wiedzy na temat indywidualnych doświadczeń rodziców i wychowawców dotyczących funkcjonowania dziecka głuchoniewidomego;

- podjęte badania jakościowe, w porównaniu do badań ilościowych, zakładają bardziej kreatywny stosunek badacza do rzeczywistości, gdyż ukierunkowują na jednostkę. W badaniach tych podstawowym elementem budowania wiedzy na temat zachowań prawidłowych i nieprawidłowych dzieci głuchoniewidomych jest jednostkowe zrozumienie i wyjaśnienie zjawiska, a nie uogólnianie i generalizowanie go. Takie podejście wynika przede wszystkim z różnic w obrębie populacji dzieci głuchoniewidomych dotyczących m.in. stopnia uszkodzenia analizatora wzroku i słuchu, współwystępowania dodatkowych niepełnosprawności, co rzutuje na psychofizyczne możliwości rozwoju. Ponadto istotne znaczenie ma tu stosunkowo mała populacja dzieci głuchoniewidomych realizująca obowiązek szkolny w placówkach kształcenia specjalnego,

- aby poznać losy pojedynczych dzieci głuchoniewidomych, dotrzeć w głąb problematyki ich zachowań, a na tym tle doświadczeń osób zajmujących się nimi konieczne jest zastosowanie badań jakościowych;

- ze względu na utrudnienia w komunikacji lub brak możliwości artykulacyjnych dzieci głuchoniewidomych konieczne wydaje się zastosowanie jakościowych metod i technik badawczych, które pozwolą na nawiązanie bezpośredniego kontaktu z rodzicami i wychowawcami internatu, w którym przebywają dzieci głuchoniewidome. Metody i techniki jakościowe umożliwiają nawiązanie partnerskiego kontaktu, co z kolei daje możliwość uzyskania informacji, których badacz nie założył sobie przed 
badaniem oraz możliwość modyfikowania opinii badanej osoby (por. Ostrowska, 2000). Badania jakościowe umożliwiają również poznanie kontekstu (okoliczności językowe, parajęzykowe i pozajęzykowe), który wydaje się istotny $\mathrm{w}$ analizie i ocenie funkcjonowania społecznego dziecka głuchoniewidomego (por. Konarzewski, 2000);

- ze względu na różnorodność i rozmiar odpowiedzi, jak również ważność przeżyć i emocji osób badanych niemożliwe staje się zastosowanie ilościowych narzędzi badawczych;

- ocena zachowań dziecka głuchoniewidomego jest elementem trudnym do zmierzenia, ponieważ taka ocena uzależniona jest od postawy wobec dziecka, stosowanych metod wychowawczych i oddziaływań edukacyjnych i rewalidacyjnych oraz doświadczeń w kontaktach $\mathrm{z}$ dzieckiem. Z tym wszystkim związane są emocje i przeżycia badanych, stąd konieczne jest tu indywidualne podejście badacza do każdego rozmówcy, ponieważ „człowiek przeżywając, doświadczając interpretuje dziejące się zdarzenia jako określone historie. Umożliwia mu to jego własne rozumienie toczących się wokół niego zdarzeń, w tym również tych, które związane są z jego własnym działaniem" (Nowak-Dziemianowicz, 2002, s. 60).

Ponadto ,zastosowanie w badaniach strategii jakościowej pozwala na podejmowanie problemów mało znanych, które badacz bardziej przeczuwa, niż o nich wie, a taka sytuacja uniemożliwia stawianie precyzyjnych hipotez, nie można, bowiem ich formułować, jeżeli badane zagadnienie jest mało znane. Podejście jakościowe zmusza badacza do rezygnacji z hipotez badawczych i zakłada swoistą bezzałożeniowość w poznawaniu natury interesującego go zjawiska" (Pilch, Baumann, 2001, s. 279-280).

Dlatego w podjętych badaniach odstąpiono od formułowania hipotez wraz z ich zmiennymi oraz wskaźnikami.

W przyjętej na wstępie procedurze postępowania badawczego, kolejnym krokiem jest dokonanie wyboru określonej metody badawczej. Należy przy tym kierować się poprawnością metodologiczna, która uwzględnia problematykę badawczą oraz rodzaj przyjętych badań - badań jakościowych. Jednakże, mając świadomość, że prowadzenie badań w ujęciu jakościowym prowadzić może do zebrania niereprezentatywnych danych, zastosowano również triangulację, która pozwala na porównywanie danych zebranych za pomocą różnych metod. Jej zadaniem jest potwierdzenie wyników badań, przez wykazanie, że niezależne pomiary są z nimi zgodne, a przynajmniej nie są sprzeczne (Miles, Huberman, 2001, s. 276). 
W wyniku zastosowania triangulacji metod i osób zebrane dane empiryczne pozwolą na opracowanie badań własnych oraz interpretację wyników badań zarówno w obrębie przypadku, jak i przypadków w przekroju.

Następnie, przedstawienia wymagają metody, techniki i narzędzia badawcze zastosowane $\mathrm{w}$ podjętych badaniach.

\section{Metoda, techniki, narzędzia badawcze}

Uwzględniając, zgodne z założeniami metodologicznymi, dostępne w badaniach jakościowych metody przyjęto, że dla zbierania danych empirycznych, które miałyby dać jak najbardziej wyczerpującą odpowiedź na pytania zadane w podjętej problematyce badawczej, najbardziej stosowna jawi się metoda wywiadu narracyjnego.

\section{Wywiad narracyjny jako metoda zbierania danych jakościowych}

„W okresie rozwoju jakościowych koncepcji badawczych oraz kształtowania się badań biograficznych w naukach społecznych, w latach siedemdziesiątych i osiemdziesiątych XX wieku, Fritz Schütze, wraz ze swoimi współpracownikami, opracował koncepcję wywiadu narracyjnego. Metoda ta mieści się w tradycji interpretacyjnych badań społecznych, w której rzeczywistość społeczną ujmuje się jako rezultat procesów interpretacji” (Jakob, 2001, s. 111).

W niniejszym opracowaniu przyjęto, za Tadeuszem Pilchem, że wywiad narracyjny to metoda (Pilch, Bauman, 2001, s. 327). W literaturze przedmiotu możemy znaleźć inne, oprócz wywiadu narracyjnego Fritza Schütza, wywiady narracyjne, np. w poszukiwaniu osobowego mitu Sama Keena, „opowiedz historię" - metafora książki w ujęciu Dona McAdamsa, typ opowieści według Lawrenca Elsbreego, typ opowieści według Northropa Frye, filozofia jednocząca Jamesa Fowlera czy scalenie w milczeniu, medytacje de Mello (por. Tokarska, 1999).

Stąd przedstawione rodzaje wywiadu narracyjnego należałoby traktować jako techniki wywiadu narracyjnego.

\section{Techniki badawcze}

Techniki badań są czynnościami określonymi przez dobór odpowiedniej metody i przez nią uwarunkowanymi. Technika badawcza, w przeciwieństwie do metody badawczej, ogranicza się do czynności pojedynczych lub pojedynczo jednorodnych (Pilch, Baumann, 2001, s. 71). 
Stąd stanowisko, że proponowany przez Fritza Schütze przebieg wywiadu narracyjnego oraz jego fazy stanowić będą technikę badawczą.

\section{Technika narracyjna Fritza Schútze}

Schemat wywiadu Fritza Schütze składa się z trzech części, do nich też odwołuje się autor w trakcie analizy zebranego materiału.

Faza pierwsza rozpoczyna się po zastosowaniu tzw. bodźców narracyjnych - polega na przedstawieniu osobie badanej dyspozycji, punktów odniesienia, według których może ona rekonstruować własne doświadczenia, snuć swą opowieść. Zadanie przeprowadzającego wywiad ogranicza się w pierwszej części (fazie) do słuchania i rejestrowania w ustalony wcześniej sposób - opowieści z jednoczesnym zaakcentowaniem zainteresowania, zachęcającym opowiadającego do rozwijania historii według własnych ujęć. W drugiej części tej fazy, gdy respondent zaznaczy, że zakończył już swą opowieść słuchający może stać się bardziej aktywny. Po zanotowaniu wypowiedzi typu: „to wszystko”, „tak właśnie było" zachęca on badanego do rozszerzenia tych części historii, które wydają mu się niejasne czy zbyt mało szczegółowe. Odnoszą się one wciąż jeszcze do tego zakresu tematycznego, który zakreślony został przez samego opowiadającego w odpowiedzi na bodźce narracyjne.

$\underline{W}$ fazie drugiej, tzw. fazie pytań zewnętrznych, przeprowadzający wywiad może już skierować rozmowę ku tym informacjom narracyjnym, które są niezbędne z punktu widzenia jego zadań badawczych.

W fazie trzeciej prosi się badanego o interpretację przywołanych we wcześniejszych etapach doświadczeń, opis zależności między nimi oraz określenie ogólnych prawidłowości (Tokarska, 1999, s. 173).

Do badań nad zachowaniami prawidłowymi i nieprawidłowymi przejawianymi przez dzieci głuchoniewidome wybrano wywiad narracyjny Fritza Schütze, gdyż jego schemat jest najbardziej adekwatny do podjętej tematyki badań. Pierwsza faza daje możliwość swobodnej wypowiedzi osoby badanej, która może opowiedzieć historię życia dziecka z perspektywy własnych doświadczeń. Badacz uważnie wsłuchując się w tę wypowiedz może po jej zakończeniu zadać pytania, które będą stanowić istotne uzupełnienie wypowiedzi osoby badanej. Kolejna faza, w której osoba przeprowadzająca badanie przygotowuje zestaw pytań dotyczących interesującego ją obszaru, daje możliwość zadawania szczegółowych pytań koncentrujących się na problemie badań. Jest to zgodne $\mathrm{z}$ założeniami metodologicznymi, bo jak podkreśla Teresa Baumann skoncentrowanie na problemie w wywiadzie jakościowym zakłada, ze badacz 
przychodzi do osoby badanej ze sprecyzowanym obszarem poszukiwań i wie, czego chce się od rozmówcy dowiedzieć. Mimo że badacz określa obszar, który chce poznać, to badany, udzielając odpowiedzi na pytania, tworzy dominanty koncepcji teoretycznej. Te koncepcje teoretyczne mogą być stale modyfikowane i weryfikowane $\mathrm{w}$ trakcie wywiadu. Istotnym elementem jest jednak to, że badacz nie informuje rozmówcy o swojej koncepcji, dlatego nie wpływa na jego wypowiedzi (Baumann, 2001, s. 332).

Ostatnia faza, faza bilansowania, pozwala osobie badanej na pewne uzupełnienie i podsumowanie wypowiedzi.

Kolejną techniką, użytą w badaniach, była analiza dokumentów.

\section{Analiza dokumentów}

Analiza dokumentów stanowi uzupełnienie danych empirycznych uzyskanych $\mathrm{z}$ analizy jakościowej zapisu wywiadu narracyjnego. W związku z tym dodatkowo, do instrumentarium badawczego, włączono analizę dokumentów dziecka głuchoniewidomego. Analizie podlegała dokumentacja medyczna oraz psychologiczno-pedagogiczna dziecka.

Analiza dokumentów stanowiła istotne uzupełnienie danych dotyczących diagnoz medycznych i psychologiczno-pedagogicznych dziecka głuchoniewidomego. Zdecydowano się na tę technikę, gdyż istniała obawa, że rodzice nie będą pamiętali danych dotyczących okresu okołoporodowego, jak również nie będą potrafili w sposób prawidłowy przedstawić stanu zdrowia dziecka, nie będą znali lub pamiętali medycznych określeń dysfunkcji narządu wzroku i słuchu oraz nie będą potrafili zdefiniować ewentualne, dodatkowe problemy zdrowotne dziecka. Takie obawy dotyczyły również diagnoz psychologiczno-pedagogicznych. Stąd poproszono rodziców o udostępnienie dokumentacji dziecka i poddano analizie książeczkę zdrowia dziecka, wypisy ze szpitali, wyniki badań okulistycznych i audiometrycznych oraz orzeczenia i opinie z poradni psychologiczno-pedagogicznych, Ośrodków Wczesnej Interwencji, itp.

Wybrane techniki badawcze wymagają określenia dostosowanych do nich narzędzi badawczych.

\section{Narzędzia badawcze}

W niniejszej pracy zastosowano dwa narzędzia badawcze: kwestionariusz biograficznego wywiadu narracyjnego i kwestionariusz analizy dokumentów. 


\section{Kwestionariusz biograficznego wywiadu narracyjnego}

Kwestionariusz biograficznego wywiadu narracyjnego został opracowany zgodnie z założeniami wywiadu narracyjnego Fritza Schütze. Skonstruowano dwie wersje kwestionariusza. Pierwszą dla rodziców, drugą dla wychowawców. Całość zawierała wyłącznie pytania otwarte.

\section{Kwestionariusz analizy dokumentów}

Skonstruowano specjalny kwestionariusz analizy dokumentów, który miał ułatwić zebranie danych dotyczących diagnoz medycznych oraz psychologiczno-pedagogicznych i funkcjonalnych dziecka.

\section{Usytuowanie metodologii w teoriach nauk społecznych}

Podjęta problematyka badawcza oraz z nią związana metodologia badań własnych: dobór badań jakościowych, zastosowanie metody wywiadu narracyjnego oraz techniki narracji Fritza Schütza i analizy dokumentów, wraz z użyciem narzędzi - kwestionariusza wywiadu narracyjnego oraz kwestionariusza analizy dokumentów spowodowała konieczność umieszczenia analizowanego zagadnienia $\mathrm{w}$ stosownym paradygmacie.

Przez paradygmat rozumie się „zbiór ogólnych i ostatecznych przesłanek w wyjaśnieniu jakiegoś obszaru rzeczywistości, przyjętych w społeczności uczonych - przedstawicieli danej dyscypliny naukowej, a następnie upowszechniony jako wzór myślenia w normalnych zbiorowościach użytkowników nauki” (Kwieciński, Witkowski 1993, s. 18). W naukach społecznych wyróżniamy:

- paradygmat humanistyczny,

- paradygmat interpretatywny,

- paradygmat strukturalistyczny,

- paradygmat funkcjonalistyczny (Kwieciński, Śliwerski, 2003, s. 61-62).

$\mathrm{Na}$ zaprezentowanym tle paradygmatów, typowych dla nauk społecznych, niniejsze badania nad problemem funkcjonowania społecznego dzieci głuchoniewidomych w wyniku edukacji rodzinnej i edukacji instytucjonalnej, w kontekście zachowań prawidłowych i nieprawidłowych, umieszczone zostały w paradygmacie interpretatywnym, gdyż będą interpretowane zmiany, jakie zachodzą u dzieci głuchoniewidomych w wyniku przejścia od edukacji rodzinnej do edukacji instytucjonalnej.

\section{Organizacja i teren badań}

Uwzględniając przesłanki metodologiczne w badaniach zastosowano dobór celowy, co oznacza, że o tym, kto zostanie zakwalifikowany do osób badanych, zadecyduje sam badacz. 


\section{Obiekty i dobór prób badawczych}

Clark Moustacas stwierdza, że w badaniach jakościowych nie ma przyjętych z góry kryteriów odnośnie do uczestników badania, a istotne kryterium stanowi to, czy uczestnik badań przeżywał dane zjawisko, czy jest silnie zainteresowany rozumieniem jego natury i jego sensu, czy zechce uczestniczyć w długim wywiadzie oraz czy udziela badaczowi prawa do rejestracji przebiegu wywiadu i godzi się na publikację danych (Moustacas, 2001, s. 132). Stąd w doborze celowym wytypowano:

- rodziców 10 dzieci głuchoniewidomych, którzy zgodzili się wziąć udział w badaniu, i których dzieci realizują obowiązek szkolny w Oddziale dla Dzieci i Młodzieży Głuchoniewidomej przy Ośrodku Szkolno-Wychowawczym Nr 1 dla Dzieci i Młodzieży Słabo Widzącej i Niewidomej im. L. Braille'a w Bydgoszczy przynajmniej od 5 lat;

- 6 wychowawców-nauczycieli dyplomowanych, z minimum 10-letnim stażem pracy pedagogicznej z dziećmi głuchoniewidomymi.

$\mathrm{Na}$ tle takiego doboru próby badawczej podmiotem badań uczyniono rodziców i wychowawców 10 głuchoniewidomych dzieci realizujących obowiązek szkolny w Oddziale dla Dzieci i Młodzieży Głuchoniewidomej przy Ośrodku Szkolno-Wychowawczym Nr 1 dla Dzieci i Młodzieży Słabo Widzącej i Niewidomej im. L. Braille'a w Bydgoszczy. Z powodu braku kontaktu werbalnego z dziećmi głuchoniewidomymi stanowią one jedynie pośredni podmiot badan.

\section{Teren badań}

Teren badań stanowił Oddział dla Dzieci i Młodzieży Głuchoniewidomej przy Ośrodku Szkolno-Wychowawczym Nr 1 dla Dzieci i Młodzieży Słabo Widzącej i Niewidomej im. L. Braille'a w Bydgoszczy. Jest to najstarsza i największa w Polsce placówka kształcąca, pochodzące z terenu całego kraju, dzieci i młodzież, z równoczesnym uszkodzeniem wzroku i słuchu.

\section{Edukacja rodzinna i edukacja instytucjonalna a funkcjonowanie społeczne dzieci głuchoniewidomych w narracjach rodziców i wychowawców}

Zgodnie z przyjętą procedurą badawczą po przeprowadzeniu badań kolejnym etapem było opracowanie i porządkowanie materiału empirycznego. 
Zgromadzone dane jakościowe, poddane zostały analizie, zgodnie z schematem opracowanym przez Fritza Schütze, który w znacznym stopniu pokrywa się z założeniami metodologicznymi, proponowanymi przez Matthew Milesa i Michaela Hubermana.

Pierwszą czynnością w schemacie analizy narracji F. Schütze jest analiza formalna tekstu wywiadu - w której następuje podział tekstu na jednostki analityczne według kryterium wyprowadzonego z narracji oraz wyłączenie $\mathrm{z}$ tekstu fragmentów nienarracyjnych. Kolejnym etapem jest kodowanie tekstu w ściśle określonej sekwencji, np. czasowej (Rubacha, 2008, s. 294).

Tym krokom odpowiada etap redukcji danych, proponowany przez M. Milesa i M. Hubermana. Redukcja danych według tych autorów odnosi się do procesu selekcji, upraszczania i przekształcania danych, które mają postać spisanych notatek terenowych bądź transkrypcji. Redukcja także zachodzi jeszcze przed rozpoczęciem badania, w sytuacji, kiedy badacz określa ramy pojęciowe, wybiera metody i osoby do badania. Redukcja następuje również w trakcie zbierania materiału badawczego oraz po zakończeniu zbierania danych, w formie spisywania podsumowań, streszczeń, wydobywania tematów, spisywania notatek, kodowania. M. Miles i M. Huberman podkreślają, że redukcja nie jest działaniem odrębnym, jest elementem i formą analizy, który wyostrza, organizuje, rozdziela i odrzuca dane, tak aby ostatecznie można je było weryfikować i wyprowadzać z nich wnioski (Miles, Huberman, 2000, s. 276).

Dalej, w swoim schemacie F. Schütze uwzględnia opis strukturalny, czyli wyodrębnienie:

- instytucjonalnych wzorów przebiegu życia, a w tym określenie przebiegu sytuacji życiowych badanego, który jest rezultatem jego przebywania w różnych instytucjach społecznych,

- biograficznych schematów działania, czyli projektów, które badany realizował w życiu, jego celowe działania,

- trajektorii - sytuacji, w których badany utracił kontrolę nad działaniem, orientację w swoim otoczeniu i doświadczył przykrych doznań, np. choroby,

- biograficznych procesów zmian, czyli sytuacji, zdarzeń, które zapoczątkowały gruntowne zmiany perspektywy życiowej badanego oraz kierunków jego działania (Rubacha 2008, s. 295).

Kolejnym krokiem jest dokonanie abstrakcji, polegające na połączeniu wyodrębnionych struktur procesowych w całościowy obraz biografii osoby badanej (Rubacha 2008, s. 294). 
Z kolei M. Miles i M. Huberman ten etap nazywają reprezentacja danych. Jest ona „zorganizowanym, poddanym kompresji zbiorem informacji, która pozwala na wyprowadzenie wniosków i podejmowanie działań" (Miles, Huberman, op. cit., s. 11). Reprezentacja może polegać na konstruowaniu matryc, grafów, sieci, wykresów, co pozwala na powiązanie zgromadzonych danych w bezpośrednio pojęte formy. Takie działanie pozwala albo na wyprowadzenie wniosków, albo na przejście do następnego etapu analizy. Reprezentacja danych, podobnie jak redukcja danych jest częścią analizy, nie jest oddzielnym od analizy działaniem badacza (Miles, Huberman, ibidem, s. 12).

Ostatnim etapem schematu analizy narracji w opracowaniu F. Schütze jest budowanie i weryfikacja teorii ugruntowanej. Tu zestawić należy wszystkie narracje, by poszukiwać regularności, porównywać przypadki podobne i odmienne. Często wykorzystujemy w tym etapie triangulację (Rubacha 2008, s. 297).

U M. Milesa i M. Hubermana analizę jakościową kończy wyprowadzanie $i$ weryfikacja wniosków. Wyprowadzanie wniosków oznacza, że „od początku wprowadzania danych, badacz jakościowy zaczyna decydować, co oznaczają dane, tj. dostrzega regularności, wzory, wyjaśnia możliwe konfiguracje, strumienie przyczynowe i stwierdzenia". Z kolei weryfikacja wniosków to testowanie tymczasowych wniosków pod względem ,ich możliwości, ich trafności, zakresu potwierdzenia - to jest ich wiarygodność" (Miles, Huberman, op. cit., s. 12).

\section{Zasady opracowywania materiału badawczego}

Stosując się do przedstawionych procedur analizy danych jakościowych oraz uwzględniając specyfikę podjętych badań podjęto kroki mające na celu opracowanie zgromadzonych danych empirycznych.

Analizę rozpoczęto od transkrypcji nagrań audio. D. Silverman wskazuje na następujące zalety transkrypcji nagrań:

- dają możliwość uchwycenia wszystkich aspektów rozmowy,

- są ogólnie dostępne, bardziej osiaggalne i możliwe do ogarnięcia przez badacza,

- można je ulepszać, przez co analiza może przybrać inny kierunek, nieograniczony początkową transkrypcja,

- dają możliwość badania sekwencji wypowiedzi, w których można uchwycić istotę rozmowy (Silverman, 2008, s. 43).

Kolejnym etapem było porzadkowanie materiatu badawczego $\mathrm{w}$ formie arkuszy i protokołów każdej z badanych osób. Następnie sporządzono i zwery- 
fikowano listę kodów według kategorii ujętych w pytaniach badawczych oraz kodowano wywiady.

Kodowanie jest analizą, która polega na podziale spisanego tekstu na części przy równoczesnym nienaruszeniu relacji między nimi. Kod jest tu oznaczeniem lub etykietą, która służy przypisywaniu jednostek znaczenia do opisywanych informacji zebranych podczas badania (Miles, Huberman, op. cit., s. 59-60).

Kody przypisuje się do fragmentów wypowiedzi, całych sekwencji albo pojedynczych zdań. Kody dają możliwość odszukania wcześniej opisanych nimi fragmentów, co ułatwia łączenie w segmenty, które badacz może przypisać do określonych problemów, konstruktów czy tematów. Dzięki nim badacz nadaje znaczenie słowom (Miles, Huberman ibidem, s. 60).

W badaniach zastosowano następującą listę kodów:

Tabela 1. Lista kodów przyjęta w badaniach własnych.

\begin{tabular}{|l|c|c|}
\hline \multicolumn{1}{|c|}{ KATEGORIA } & KOD & $\begin{array}{c}\text { PROBLEM } \\
\text { BADAWCZY }\end{array}$ \\
\hline $\begin{array}{l}\text { Funkcjonowanie społeczne } \\
\text { dziecka głuchoniewidomego } \\
\text { a edukacja rodzinna }\end{array}$ & FSR & 1 \\
\hline Postawy rodzicielskie wobec dziecka głuchoniewidomego & FSR - PR & 1.1. \\
\hline $\begin{array}{l}\text { Zmiana postaw rodzicielskich w miarę dorastania dziecka głucho- } \\
\text { niewidomego }\end{array}$ & FSR - PR - Z & 1.2. \\
\hline KATEGORIA & KOD & $\begin{array}{c}\text { PROBLEM } \\
\text { BADAWCZY }\end{array}$ \\
\hline $\begin{array}{l}\text { Style i metody wychowawcze stosowane wobec dziecka głucho- } \\
\text { niewidomego }\end{array}$ & FSR - SMW & 1.3. \\
\hline $\begin{array}{l}\text { Zmiana stylów wychowania i metod wychowawczych w miarę } \\
\text { dorastania dziecka głuchoniewidomego }\end{array}$ & FSR - SMW - Z & 1.4. \\
\hline $\begin{array}{l}\text { Zachowania prawidłowe przejawiane przez dziecko głuchoniewi- } \\
\text { dome do czasu podjęcia nauki w Ośrodku }\end{array}$ & FSR - ZP - D & 1.5 \\
\hline $\begin{array}{l}\text { Zachowania nieprawidłowe przejawiane przez dziecko głuchonie- } \\
\text { widome do czasu podjęcia nauki w Ośrodku }\end{array}$ & FSR - ZNP - D & 1.5 \\
\hline $\begin{array}{l}\text { Zachowania prawidłowe przejawiane przez dziecko głuchoniewi- } \\
\text { dome po podjęciu nauki w Ośrodku }\end{array}$ & FSR - ZP - 0 & 1.6. \\
\hline $\begin{array}{l}\text { Zachowania nieprawidłowe przejawiane przez dziecko głuchonie- } \\
\text { widome po podjęciu nauki w Ośrodku }\end{array}$ & FSR - ZNP - 0 & 1.6. \\
\hline $\begin{array}{l}\text { Zmiany w zachowaniu dziecka głuchoniewidomego po podjęciu } \\
\text { nauki w Ośrodku }\end{array}$ & FSR - ZZ - 0 & 1.7 \\
\hline $\begin{array}{l}\text { Przyczyny zmian w zachowaniu dziecka głuchoniewidomego po } \\
\text { podjęciu nauki w Ośrodku }\end{array}$ & FSR - ZZ - 0 - P & 1.8 \\
\hline
\end{tabular}


Tabela 1. Cd.

\begin{tabular}{|l|c|c|}
\hline $\begin{array}{l}\text { Różnice między zachowaniem dziecka głuchoniewidomego } \\
\text { w domu i w Ośrodku }\end{array}$ & FSR - ZDO - R & 1.9. \\
\hline $\begin{array}{l}\text { Przyczyny różnic w zachowaniu dziecka głuchoniewidomego } \\
\text { w domu i w Ośrodku }\end{array}$ & FSR - ZDO - R - P & 1.10. \\
\hline $\begin{array}{l}\text { Funkcjonowanie społeczne } \\
\text { dziecka głuchoniewidomego } \\
\text { a edukacja instytucjonalna }\end{array}$ & FSI & 2 \\
\hline $\begin{array}{l}\text { Zachowania prawidłowe przejawiane przez dziecko głuchoniewi- } \\
\text { dome po przyjęciu go do Ośrodka }\end{array}$ & FSI - ZP - PO & 2.1. \\
\hline $\begin{array}{l}\text { Zachowania nieprawidłowe przejawiane przez dziecko głuchonie- } \\
\text { widome po przyjęciu go do Ośrodka }\end{array}$ & FSI - ZNP - PO & 2.1. \\
\hline $\begin{array}{l}\text { Działania wychowawców w celu niwelowania zachowań niepra- } \\
\text { widłowych }\end{array}$ & FSI - ZNP - DW & 2.2. \\
\hline KATEGORIA & KOD & $\begin{array}{c}\text { PROBLEM } \\
\text { BADAWCZY }\end{array}$ \\
\hline $\begin{array}{l}\text { Działania wychowawców w celu wzmacniania zachowań prawi- } \\
\text { dłowych }\end{array}$ & FSI - ZP - DW & 2.2. \\
\hline $\begin{array}{l}\text { Zmiany w zachowaniu dziecka głuchoniewidomego pod wpływem } \\
\text { systemowych oddziaływań edukacyjnych i rewalidacyjnych }\end{array}$ & FSI - ZZ - EI & 2.3. \\
\hline $\begin{array}{l}\text { Przyczyny zmian w zachowaniu dziecka głuchoniewidomego pod } \\
\text { wpływem edukacji instytucjonalnej }\end{array}$ & FSI - ZZ - EI - P & 2.4. \\
\hline $\begin{array}{l}\text { Różnice między zachowaniem dziecka głuchoniewidomego po } \\
\text { dłuższym pobycie w domu i w Ośrodku }\end{array}$ & FSI - ZDO - R & 2.5. \\
\hline $\begin{array}{l}\text { Przyczyny różnic w zachowaniu dziecka głuchoniewidomego po } \\
\text { dłuższym pobycie w domu i w Ośrodku }\end{array}$ & FSI - ZDO - R - P & 2.6. \\
\hline Żodo: opacowe who & \\
\hline
\end{tabular}

Źródło: opracowanie własne

Kolejnym krokiem było sporządzenie matryc do reprezentacji w ramach przypadku i reprezentacji przypadków w przekroju.

Do opisu w ramach przypadku skonstruowano:

- mapę kontekstową wywiadu,

- matrycę uporządkowaną pojęciowo,

- trajektorię życia dziecka,

- mapę reakcji rodzica na zachowania prawidłowe i nieprawidłowe dziecka głuchoniewidomego,

- mapę reakcji wychowawców na zachowania prawidłowe i nieprawidłowe dziecka głuchoniewidomego,

- mapę porównującą reakcje rodzica i wychowawcy na zachowania prawidłowe i nieprawidłowe dziecka głuchoniewidomego,

- model sieci przyczynowej. 
Aby ułatwić czytanie matrycy i map oraz ułatwić wyprowadzenie wniosków zastosowano takie same kolory, jakich użyto w ramie pojęciowej problemów badawczych.

Mapa kontekstowa wywiadu zawierała informacje dotyczące przebiegu badania, w tym:

- termin, miejsce i czas trwania wywiadu,

- podstawowe informacje o badanym,

- atmosfera badania,

- warunki badania,

- zachowanie osoby badanej,

- zachowanie badacza,

- uwagi.

Matryca uporządkowana pojęciowo musi być tak skonstruowana, że:

- przedstawia się na jednym arkuszu wszystkie mające znaczenie odpowiedzi kluczowe informatorów,

- pozwala na wstępne porównywanie między informatorami oraz pojęciami,

- pozwala zauważyć, w jaki sposób poddać dane dalszej analizie,

- pozwala na wykonanie analiz poprzecznych,

- dostarcza zestawu tematów wynikających z analizy treści (Miles, Huberman, op. cit., s. 133).

W matrycy uwzględniono przejawy zachowań prawidłowych i nieprawidłowych dziecka głuchoniewidomego w kontekście edukacji rodzinnej i instytucjonalnej. Istotny był tu podział na czasookresy (przed przyjęciem do Ośrodka, przed i zaraz po przyjęciu do Ośrodka, po dłuższych pobytach w domu, od momentu przyjęcia do Ośrodka), które stanowią istotny czynnik wykazania ewentualnych różnic $\mathrm{w}$ zachowaniu dziecka głuchoniewidomego w domu i w Ośrodku. Umieszczenie danych w matrycy odbywało się za pomocą wcześniej zakodowanych tekstów pogrupowanych pojęciowo według kodów. Badacz zredukował dane do etykiety, którą sam nazwał, cytatów, którymi ilustrował daną etykietę oraz zwrotów streszczajacych w sytuacji, kiedy dane w wywiadzie były rozproszone i trudno było zilustrować etykietę poprzez jeden wybrany cytat. Matryce uporządkowane pojęciowo dały badaczowi możliwość wyciagania wniosków. Poprzeczne czytanie wierszy dało zwarty obraz każdego informatora, co pozwoliło na wstępne sprawdzenie relacji między odpowiedziami na różne pytania. Czytanie wzdłuż kolumn pozwoliło na dokonywanie porównań między informacjami od różnych informatorów. Takie czytanie matrycy prowadziło do większej liczby wniosków. 
Trajektoria życia zilustrowana została przez oś, na której zaznaczone zostały daty istotnych zmian w życiu dziecka, tj. np. uzyskanie diagnozy o dysfunkcji dziecka, formy wsparcia, przyjęcie do Ośrodka.

Mapa reakcji rodzica na zachowania prawidłowe i nieprawidłowe dziecka głuchoniewidomego, w której przedstawione zostały zachowania prawidłowe i nieprawidłowe dziecka głuchoniewidomego wraz z reakcjami rodzica na przejawy takich zachowań z uwzględnieniem okresu przed i po przyjęciu do Ośrodka.

Mapa reakcji wychowawców na zachowania prawidłowe i nieprawidłowe dziecka głuchoniewidomego, w której przedstawione zostały zachowania prawidłowe i nieprawidłowe dziecka głuchoniewidomego wraz z reakcjami wychowawców na przejawy takich zachowań z uwzględnieniem znaczących okresów zmian po przyjęciu do Ośrodka.

Mapa porównująca reakcje rodzica i wychowawców na zachowania prawidłowe i nieprawidłowe dziecka głuchoniewidomego, w której przedstawiono podobieństwa i różnice $\mathrm{w}$ reakcjach rodziców i wychowawców na zachowania prawidłowe i nieprawidłowe dziecka głuchoniewidomego.

Sieć przyczynowa służy ,zobrazowaniu istniejących połączeń między badanymi zjawiskami” (Pilch, Baumann 2001, s. 346). Skonstruowano sieć przyczynową ukazującą zmiany w zachowaniu dzieci głuchoniewidomych w wyniku edukacji rodzinnej i instytucjonalnej, zakładając wzajemny wpływ różnych czynników. Każda sieć miała dołączony tekst analityczny, opisujący znaczenie powiązań między poszczególnymi czynnikami. Narracja zamieszczona pod każdą siecią ułożona była chronologicznie, co umożliwiło śledzenie sieci.

Zbudowano także matrycę - reprezentację przypadków w przekroju, w której zebrano wszystkie przypadki. Matryca ta jest zbiorczym arkuszem, łączącym dane opisowe z każdego, z poszczególnych przypadków. Podstawową zasadą jej tworzenia jest zebranie skondensowanych, wszystkich ważnych danych (por. Miles, Huberman 2000). Stąd informacje w niej zawarte nie zawierają cytatów i podsumowują poszczególne matryce każdego przypadku.

Kolejnym krokiem, po opracowaniu i porządkowaniu zgromadzonego materiału, wynikającym z przyjętej procedury badawczej, były opis i analiza danych empirycznych.

\section{Prezentacja indywidualnych przypadków}

Prezentacje indywidualnych przypadków rozpoczęto od ucznia, który najdłużej przebywa w Oddziale dla Dzieci i Młodzieży Głuchoniewidomej w Byd- 
goszczy, a zakończono na uczniu, który przebywa najkrócej. Każdy przypadek omawiano w identyczny sposób, tzn. analizę przypadku rozpoczyna „Matryca uporządkowana pojęciowo”. Następnie ukazano „Trajektorię życia”. Kolejno zaprezentowano „Mapę reakcji rodziców na zachowania prawidłowe i nieprawidłowe” i „Mapę reakcji wychowawców na zachowania prawidłowe i nieprawidłowe”, które porównano w „Mapie reakcji na zachowania prawidłowe i nieprawidłowe. Całość zamyka „Sieć przyczynowa zachowań prawidłowych i nieprawidłowych przed i po przyjęciu do Ośrodka”. Na jej tle następuje „Opis sieci przyczynowej”. Końcowym etapem prezentacji przypadku jest „Analiza $\mathrm{i}$ interpretacja w oparciu o wybrane teorie naukowe".

\section{Prezentacja przypadków w przekroju}

Prezentację „Przypadków w przekroju” przedstawiono według kolejności omawianych wcześniej przypadków indywidualnych. W tym zestawieniu próbowano, z pewnym prawdopodobieństwem, dać odpowiedź na pytania o przyczyny występowania u uczniów Oddziału dla Dzieci i Młodzieży Głuchoniewidomej w Bydgoszczy zachowań prawidłowych i nieprawidłowych.

Kończąc rozważania dotyczące analizy jakościowej zachowań prawidłowych i nieprawidłowych uczniów głuchoniewidomych na tle edukacji rodzinnej i instytucjonalnej istotne jest zaprezentowanie rzetelności stosowanych sposobów pomiaru na tle literatury przedmiotu.

Podstawowym zarzutem stawianym badaniom jakościowym jest ich subiektywność. Jednakże D. Urbaniak-Zając wskazuje, że „w tej orientacji metodologicznej zarówno badacz, jak i osoby badane są postrzegane jako refleksyjni uczestnicy interakcji przebiegającej w danym kontekście społecznym. Po drugie, deklarowanym celem badań jakościowych jest zdobywanie nowej wiedzy, nowego poznania, budowanie teorii, a nie sprawdzanie już istniejących (Urbaniak-Zając 2006, s. 212). Tym samym jedno z kryteriów badań ilościowych obiektywność nie znajduje zastosowania w podjętych badaniach.

Drugim poddanym ocenie kryterium jest rzetelność, która odnosi się do stałości otrzymywanych wyników za każdym razem, gdy badamy ten sam obiekt. „W badaniach jakościowych, gdy duże znaczenie przypisuje się kontekstowi analizowanych zjawisk, w których mamy do czynienia z otwartością sytuacji zbierania danych, każde badanie jest niepowtarzalne. Można, naturalnie, powtórzyć na przykład wywiady narracyjne, ale nieuzasadnione jest oczekiwanie, że ich przebieg za drugim razem będzie identyczny jak za pierwszym" (Urbaniak-Zając, ibidem, s. 212). 
„Kolejnym kryterium oceny badań empirycznych jest trafność. [...] $\mathrm{Na}$ przykład D. Campbell rozróżnia trafność wewnętrzną i zewnętrzną. W pierwszym przypadku chodzi o sprawdzenie, czy przyjęty sposób postępowania rzeczywiście bada to, co było zamierzone, a dokładnie, czy zmiany zmiennej zależnej są wynikiem wyłącznego oddziaływania zmiennej niezależnej. Udzielenie odpowiedzi na to pytanie wymaga spełnienia co najmniej kilku podstawowych warunków: istnieje możliwość wyodrębnienia wszystkich zmiennych istotnie charakteryzujących badane zagadnienie, związki między izolowanymi zmiennymi mają charakter przyczynowy, istnieje możliwość kontroli wszystkich zmiennych. W badaniach jakościowych warunki te nie mogą być spełnione, choćby dlatego, że ten typ badań próbuje śledzić złożoność i kompleksowość codziennych doświadczeń ludzi. Trafność zewnętrzna odnosi się zaś do dopuszczalnego zakresu uogólniania wyników osiągniętych w badaniach. Jak wiadomo, w klasycznym ujęciu jest on uzależniony przede wszystkim od stopnia reprezentatywności próby badawczej i od wielkości populacji generalnej. Tak rozumiana miara trafności nie jest również adekwatna do badań jakościowych, ponieważ stosuje się w nich nie losowy dobór próby badawczej, lecz dobór teoretyczny" (Urbaniak-Zając, ibidem, s. 213).

Z powyższych rozważań wynika, że tradycyjne kryteria badań empirycznych nie znajdują zastosowania $w$ badaniach jakościowych. Niemniej jednak badacze podjęli próby stworzenia kryteriów badań jakościowych (por. Urbaniak-Zając, ibidem, s. 214-215).

Wśród wielu podejść propozycja Inez Steinke wydaje się najbardziej trafiona. Wyróżnia ona następujące kryteria dla oceny badań jakościowych:

1. Umożliwienie intersubiektywnego odtworzenia przebiegu procesu badawczego. Można to osiagnąć nie tylko poprzez szczegółową dokumentację formalno-technicznych rozstrzygnięć (sposób zbierania danych, reguły transkrypcji), stawianych pytań badawczych, tymczasowo przyjmowanych hipotez, kontekstu badań, ale także poprzez opis dynamiki relacji badacz-badani, opis przedwiedzy badacza, jego obaw i lęków. Informacje takie są ważne jako podstawa do dalszej analizy, pozwalają czytelnikowi śledzić subiektywne komponenty procesu badawczego, poza tym ich podanie zmusza badacza do refleksyjnego, świadomego podejmowania decyzji.

2. Sprawdzanie adekwatności procedury badawczej do badanego zagadnienia. Autor badań powinien umieć uzasadnić, dlaczego wybrał taką a nie inną procedurę badań jakościowych, scharakteryzować czas spędzony w terenie, by dać czytelnikowi możliwość oceny, czy pobyt badacza w terenie był odpowiednio długi, by mógł się zbliżyć do co- 
dzienności badanych, by między badaczem a badanymi powstała relacja umożliwiająca powstanie owocnych danych (otwartość, zaufanie, gotowość do pracy itp.).

3. Empiryczne ugruntowanie teorii i empiryczne sprawdzenie teorii. Badania jakościowe są ukierunkowane na budowanie teorii przy wykorzystaniu orientacji indukcyjnej, ewentualnie postawy abdukcyjnej. Celem jest odkrycie czegoś nowego, co tkwi w danych (oddających codzienne doświadczenia ludzi), a co nie jest wyprowadzone z istniejącej już (przed)wiedzy teoretycznej.

4. Wskazywanie granic ważności wyników. Wprawdzie w badaniach jakościowych podkreśla się lokalny i czasowy charakter budowanych teorii, niemniej większa ogólność teorii nie jest jej wadą, lecz zaletą. Badacz powinien więc dokonywać możliwych uogólnień, przy jednoczesnym wskazywaniu granic obowiązywania zbudowanej teorii. Może to osiągnąć poprzez wskazywanie warunków i kontekstów ważnych dla analizowanych zjawisk, poprzez określenie innych kontekstów, w jakich można uogólniać uzyskane wyniki. Badacz powinien starać się odpowiedzieć na pytanie: jakie minimalne lub wystarczające warunki muszą być spełnione, by pojawiały się opisywane przez teorię zjawiska.

5. Refleksja nad subiektywnością. Refleksyjność badacza jest warunkiem prowadzenia badań, a subiektywność - jego niezbywalną cechą której nie można zlikwidować, lecz należy ją świadomie wykorzystywać, to znaczy znać korzyści i potencjalne niebezpieczeństwa. Badacz nie powinien odrzucać, czy ukrywać przed sobą lęków, niepewności, irytacji, konfliktów itp., których doświadcza w trakcie badań. Te stany emocjonalne należy traktować jako dane, w kontekście których wyraźnie widzimy niezgodności między naszą przedwiedzą a sytuacjami, poglądami czy postawami uczestników badań.

6. Wewnętrzna zgodność. To kryterium nie może być traktowane samodzielnie. Przywołanie kryterium wewnętrznej zgodności zwraca uwage na to, że w badaniach jakościowych nie należy rezygnować $\mathrm{z}$ posługiwania kryterium logiki. Niemniej kryteria te nie mogą dominować (Urbaniak-Zając 2006, s. 220-221).

Stosując powyższe kryteria można przyjąć, że podjęte badania będą w swoim całokształcie rzetelne, gdyż:

a. zastosowano odpowiedni model badan - indukcję,

b. dane będą zbierane poprzez wywiad narracyjny i analizę dokumentów techniki uznane i stosowane w badaniach jakościowych, 
c. czas spędzony z badanymi - 9 lat pracy w Oddziale dla Dzieci i Młodzieży Głuchoniewidomej pozwala na nawiązanie bliskich relacji zarówno z rodzicami, jak i wychowawcami internatu,

d. doświadczenie nabyte w pracy z dziećmi głuchoniewidomymi, których dotyczyć będą wywiady narracyjne, pozwala mimo subiektywnego podejścia na znaczny obiektywizm.

\section{Bibliografia}

Baumann T. (2001), Strategie jakościowe w badaniach pedagogicznych w: Pilch T., Baumann T., Zarys badań pedagogicznych. Strategie ilościowe i jakościowe, Wyd. Akademickie Żak, Warszawa.

Brzeziński J. (2004), Metodologia badań pedagogicznych, PWN, Warszawa.

Jakob G. (2001), Wywiad narracyjny w badaniach biograficznych w: Urbaniak-Zając D., Piekarski J., Jakościowe orientacje w badaniach pedagogicznych, Wydawnictwo Uniwersytetu Łódzkiego, Łódź.

Konarzewski K. (2000), Jak uprawiać badania oświatowe. Metodologia praktyczna, WSiP, Warszawa.

Kwieciński Z., Śliwerski B. (red.) (2003), Pedagogika. Podręcznik akademicki, cz. I, Wydawnictwa Naukowe PWN, Warszawa.

Kwieciński Z., Witkowski I. (red.) (1993), Spory o edukację: dylematy i kontrowersje we współczesnych pedagogiach: zbiór, Instytut Badań Edukacyjnych, Warszawa-Toruń.

Miles M. B., Huberman A. M. (2000), Analiza danych jakościowych, Trans Humana, Białystok.

Moustacas C. (2001), Fenomenologiczne metody badań, Trans Humana, Białystok.

Nowak-Dziemianowicz M. (2002), Doświadczenia rodzinne w narracjach. Interpretacja sensów i znaczeń, Wyd. Uniwersytetu Wrocławskiego, Wrocław.

Ostrowska U. (2000), Dialog w pedagogicznym badaniu jakościowym, Oficyna Wydawnicza Impuls, Kraków.

Pilch T., Baumann T. (2001), Zarys badań pedagogicznych. Strategie ilościowe i jakościowe, Wydawnictwo Akademickie Żak, Warszawa.

Pilch T., Lepaczyk I. (red.) (2004), Pedagogika społeczna: człowiek w zmieniajacym się świecie, Wydawnictwo Akademickie Żak, Warszawa.

Rubacha K. (2008), Metodologia badań nad edukacja, Wydawnictwo Akademickie i Profesjonalne, Warszawa. 
Silverman D. (2008), Prowadzenie badań jakościowych, PWN, Warszawa.

Szlachta B (red.) (2004), Słownik społeczny, Wydawnictwo WAM, Kraków.

Tokarska U. (1999), W poszukiwaniu jedności i celu. Wybrane techniki narracyjne, w: Gałdowa A. (red.), Wybrane zagadnienia z psychologii osobowości, Wydawnictwo Uniwersytetu Jagiellońskiego, Kraków.

Urbaniak-Zając D. (2006) W poszukiwaniu kryteriów oceny badań jakościowych w: Kubinowski D., Nowak M. (red.), Metodologia pedagogiki zorientowanej humanistycznie, Oficyna Wydawnicza Impuls, Kraków.

\section{Analysis of quality data correct and incorrect behaviors of deaf-blind children in family and institutional education - methodological solutions}

\section{Summary}

The researches were focused on correct and incorrect bahaviour of deaf-blind children and made according to the research practise and were divided into following steps:

- the researched tools were prepared, collecting of empiric data step where deaf-blind children's parents and teachers were interviewed and recorded,

- studing and ordering of data step where interviews were written down, transcripted and coded,

- description and analysis step where individual cases observed and analised,

- conclusion step.

Keywords: Analysis of quality data, institutional education, deaf-blind children, family of deaf-blind children. 